\title{
Pengaruh Rasio Keuangan, Ukuran Entitas, dan Ukuran KAP Terhadap Audit Report Lag
}

\author{
D.E. Fitriana ${ }^{1}$, Syaiful Bahri ${ }^{2}$ \\ Institut Teknologi Dan Bisnis Asia Malang \\ 1.
}

*Corresponding Author

Diajukan : 20 Januari 2022

Disetujui : 25 Januari 2022

Dipublikasi : 29 Januari 2022

\begin{abstract}
This study aims to determine and analyze the effect of profitability, solvency, liquidity, entity size, and KAP size on audit report lag (ARL). ARL is the length of time it takes from closing the books until the independent auditor's report is signed by KAP. The research population is trade, service and investment sector entities listed on the Indonesia Stock Exchange for the period 2017-2019. Non-probability sampling technique with purposive sampling method with a total of 51 entities. The data analysis technique is multiple regression analysis. The results show that profitability has a significant negative effect on audit report lag, meaning that high profitability will shorten the length of audit reporting time. Solvency, liquidity, entity size, and KAP size variables have no effect on audit report lag.
\end{abstract}

Kata kunci: Profitabilitas, Solvabilitas, Likuiditas, Ukuran Entitas, Ukuran KAP, Audit Report Lag

\section{Latar Belakang}

\section{PENDAHULUAN}

Laporan keuangan diterbitkan secara berkala, baik per bulan, per tiga bulan atau per tahun sesuai kebutuhan serta kebijakan. Laporan keuangan untuk mengukur kinerja dan analisis keadaan entitas, serta sebagai alat komunikasi kepada pihak-pihak yang perlu mengambil keputusan terkait entitas. Pihak-pihak yang berkepentingan terhadap laporan keuangan selain manajemen, seperti pemegang saham, kreditur, pemerintah dan masyarakat umum. Laporan keuangan disusun sesuai dengan ketentuan yang berlaku agar semua pihak dapat terpenuhi kebutuhannya akan laporan keuangan.

Entitas publik memiliki kewajiban menyampaikan laporan keuangan tahunan yang telah diaudit secara berkala pada Bursa Efek Indonesia (BEI). Laporan keuangan auditan merupakan laporan keuangan dari entitas yang telah diperiksa disertai dengan opini audit oleh akuntan publik terdaftar di Otoritas Jasa Keuangan (OJK). Batas waktu dalam penyampaian laporan keuangan auditan tahunan dalam Surat Keputusan Direksi PT Bursa Efek Indonesia Nomor Kep-00015/BEI/01-2021 paling lambat pada akhir bulan ketiga setelah tanggal laporan keuangan auditan tahunan (Bursa Efek Indonesia, 2021). Entitas publik yang melewati batas waktu dalam penyampaian laporan keuangan akan diberikan sanksi oleh bursa. Sanksi bagi entitas publik berupa peringatan tertulis, denda, dan penghentian sementara perdagangan efek (suspensi) di bursa sesuai dengan lama waktu keterlambatan berdasar Keputusan Direksi PT Bursa Efek Jakarta Nomor: Kep-307/BEJ/072004 (Bursa Efek Indonesia, 2004). 
Audit report lag (ARL) merupakan lama waktu yang dibutuhkan sejak tutup buku entitas hingga ditandatangani laporan auditor independen oleh akuntan publik. ARL menggambarkan jumlah waktu penyelesaian proses audit laporan keuangan yang dilakukan auditor independen. ARL dapat berlangsung lebih cepat atau lebih lambat dari batas waktu penyampaian laporan keuangan auditan. Berdasarkan data yang dihimpun, terdapat 51 entitas berdasarkan jumlah sampel yang diteliti menyampaikan laporan keuangan auditan melewati batas waktu setiap tahunnya meningkat. Entitas memerlukan waktu lebih dari 60 hari untuk menyampaikan laporan keuangan auditan. Bursa Efek Indonesia (BEI) mencatat baru 578 perusahaan tercatat yang menyampaikan laporan keuangan semester I-2019 tepat waktu. Hingga saat ini, total perusahaan tercatat di BEI adalah 737 perusahaan. Ini artinya baru 78,4\% dari total emiten yang melaporkan keuangan semester I-2019 tepat waktu. (Nurdiana, 2019). ARL setiap entitas yang tinggi dipengaruhi beberapa faktor, termasuk faktor dari dalam entitas ataupun dari luar.

ARL telah banyak diteliti, diantaranya (Artaningrum et al., 2017), (Ayuningtyas \& Riduwan, 2020), (Deasy \& Iskak, 2021), (Fadrul et al., 2021), (Lesmana, 2021), (Mahendra, 2021), (Menajang et al., 2019), (Rahayu et al., 2021), (Sartika, 2017), (Sastrawan \& Latrini, 2016), (Setyawan, 2020), (Siregar \& Sujiman, 2021), (Suginam, 2016), (Sunarsih et al., 2021), (Tampubolon \& Siagian, 2020), (Tannuka, 2018), (Widiastuti \& Kartika, 2018), dan (Yunita et al., 2020). Hasil penelitian menunjukkan ketidakkonsistenan sehingga perlu dilakukan penelitian lebih lanjut. Penelitian ini mengkaji hubungan variabel rasio keuangan (profitabilitas, solvabilitas, likuiditas), ukuran entitas, dan ukuran KAP terhadap ARL.

Rasio keuangan yang pertama adalah rasio profitabilitas diduga memengaruhi ARL. Rasio profitabilitas merupakan rasio untuk menilai kemampuan dalam mencari keuntungan sehingga memberikan ukuran tingkat efektivitas manajemen. Hal ini dibuktikan dengan laba yang dihasilkan dari penjualan dan pendapatan investasi. Naik turunnya profitabilitas berpengaruh terhadap ARL bahwa setiap kenaikan rasio profitabilitas akan menurunkan ARL. Rasio keuangan kedua adalah rasio solvabilitas yang diduga memengaruhi ARL. Solvabilitas untuk mengukur kemampuan dalam memenuhi semua kewajibannya (Muslichah \& Bahri, 2021). Solvabilitas berpengaruh positif terhadap ARL. Setiap kenaikan rasio solvabilitas menaikkan ARL. Rasio likuiditas untuk mengukur kemampuan dalam membayar kewajiban jangka pendek. Likuiditas berpengaruh terhadap ARL. Setiap kenaikan atau penurunan rasio likuiditas akan menaikkan atau menurunkan ARL.

Faktor ukuran entitas diduga berpengaruh terhadap ARL. Perusahan besar sangat memperhatikan waktu publikasi pelaporan. Banyak keputusan/ hasil keuangan yang dipengaruhi ukuran entitas. Ukuran KAP diduga berpengaruh terhadap ARL. Entitas yang menggunakan KAP besar cenderung memperpendek ARL. Ukuran KAP merupakan besar atau kecilnya nilai Kantor Akuntan Publik (KAP) ditinjau dari indikator tertentu. Ukuran KAP berhubungan dengan reputasi yang dimiliki auditor. Menurut Peraturan Menteri Keuangan Nomor 17/PMK.01/2008 Tentang Jasa Akuntan Publik, Kantor Akuntan Publik yang selanjutnya disebut KAP adalah badan usaha yang telah mendapatkan izin dari Menteri sebagai wadah bagi Akuntan Publik dalam memberikan jasanya (Kementerian Keuangan Republik Indonesia, 2008).

Rumusan masalah penelitian adalah apakah profitabilitas, solvabilitas, likuiditas, ukuran entitas, dan ukuran KAP berpengaruh terhadap ARL pada entitas sektor Perdagangan, Jasa dan Investasi yang terdaftar pada Bursa Efek Indonesia. Tujuan penelitian adalah untuk mengetahui dan menganalisis pengaruh profitabilitas, solvabilitas, likuiditas, ukuran entitas dan ukuran KAP berpengaruh terhadap ARL pada entitas sektor perdagangan, jasa dan investasi yang terdaftar pada Bursa Efek Indonesia. 
Owner: Riset \& Jurnal Akuntansi

e-ISSN : 2548-9224 | p-ISSN : 2548-7507

Volume 6 Nomor 1, Januari 2022 


\section{STUDI LITERATUR}

\section{Signalling Theory}

Eksekutif entitas memiliki kualitas informasi lebih baik mengenai entitas akan menyampaikan informasi tersebut untuk meningkatkan investasi dan nilai saham (Ross, 1977). Entitas publik menggunakan laporan keuangan sebagai media untuk menyampaikan sinyal mengenai keadaan entitas. Akurasi dan ketepatan waktu dalam penyampaian laporan keuangan entitas publik merupakan sinyal kepada pengguna laporan keuangan. Sinyal bahwa entitas memiliki kabar baik yang diharapkan segera tersampaikan pada publik. Laporan keuangan yang akurat dan tepat waktu mempermudah pengguna laporan keuangan dalam pengambilan keputusan. Laporan keuangan auditan yang tepat waktu dalam penyampaiannya menunjukkan informasi entitas telah sesuai dengan yang sebenarnya dalam pemeriksaan auditor.

\section{Audit Report Lag}

Menurut (Tambunan, 2014) audit report lag adalah lamanya waktu penyelesaian audit yang diukur dari tanggal penutupan tahun buku (akhir tahun fiskal) hingga tanggal diterbitkannya laporan keuangan auditan. Audit report lag adalah panjangnya waktu akhir tahun fiskal suatu entitas dengan tanggal yang tertera dalam laporan audit. Ketepatan waktu entitas dalam mempublikasikan laporan keuangan kepada stakeholder tergantung dari ketepatan waktu auditor dalam menyelesaikan pekerjaan auditnya. Dengan kemungkinan yang ada, auditor tidak dapat menyelesaikan dengan tepat waktu sehingga auditor mengeluarkan laporan keuangan yang terlalu lama dan mengakibatkan stakeholder ragu akan kualitas informasi yang dipublikasikan.

\section{Profitabilitas}

Menurut (Bahri, 2017) rasio profitabilitas adalah kemampuan entitas memperoleh laba dalam hubungannya dengan penjualan, total aset, maupun modal sendiri. Bagi investor jangka panjang sangat berkepentingan dengan informasi profitabilitas. Rasio ini juga memberikan ukuran tingkat efektivitas manajemen. Hal ini ditunjukkan oleh laba yang dihasilkan dari penjualan dan pendapatan investasi. Initinya bahwa penggunaan rasio ini menunjukkan efisiensi entitas.

\section{Solvabilitas}

Solvabilitas adalah kemampuan entitas membayar semua kewajibannya. Entitas yang mempunyai kecukupan aset untuk membayar utangnya disebut solvable, sedangkan yang tidak mampu disebut unsolvable (Muslichah \& Bahri, 2021). Kemampuan dalam melunasi kewajibannya menunjukkan kinerja yang baik.

\section{Likuiditas}

Rasio likuiditas (liquidity ratio) menggambarkan kemampuan dalam memenuhi kewajiban jangka pendek (Muslichah \& Bahri, 2021). Rasio likuiditas berfungsi mengukur kemampuan entitas dalam memenuhi kewajiban yang telah jatuh tempo, baik kewajiban kepada pihak luar entitas maupun di dalam.

\section{Ukuran Entitas}

Menurut (Asnawi \& Wijaya, 2005) ukuran entitas merupakan variabel kontrol yang dipertimbangkan dalam banyak penelitian keuangan. Hal ini disebabkan dugaan banyaknya keputusan/hasil keuangan dipengaruhi oleh ukuran entitas. Ukuran entitas (firm size) adalah 
besar kecilnya entitas dapat diukur dengan total aset/ besar harta entitas dengan menggunakan perhitungan nilai logaritma total aset (Bahri, 2017).

\section{Ukuran KAP}

Entitas cenderung menggunakan jasa Kantor Akuntan Publik (KAP) yang besar dan mempunyai nama baik untuk menjamin kredibilitas dari laporan keuangan. KAP di Indonesia dibagi menjadi KAP big four dan KAP non-big four, KAP internasional atau yang dikenal dengan the big four diasumsikan dapat melaksanakan pekerjaan auditnya secara efisien dan memiliki tekanan waktu yang lebih tinggi untuk menyelesaikan audit tepat pada waktunya (Widiastuti \& Kartika, 2018) dan (Rahayu et al., 2021). Kantor Akuntan Publik (KAP) di Indonesia yang berafiliasi dengan KAP internasional atau the big four:

1. PricewaterhouseCoopers (PwC) berafiliasi dengan KAP Tanudiredja, Wibisana, Rintis dan Rekan.

2. Ernst \& Young (EY) berafiliasi dengan KAP Purwantono, Suherman dan Surja.

3. Deloitte berafiliasi dengan KAP Satrio Bing Eny dan Rekan sampai 2018, dengan KAP Imelda dan Rekan.

4. Klynveld Peat Marwick Goerdeler (KPMG) dengan KAP Siddharta Widjaja \& Rekan.

\section{Kerangka Konseptual}

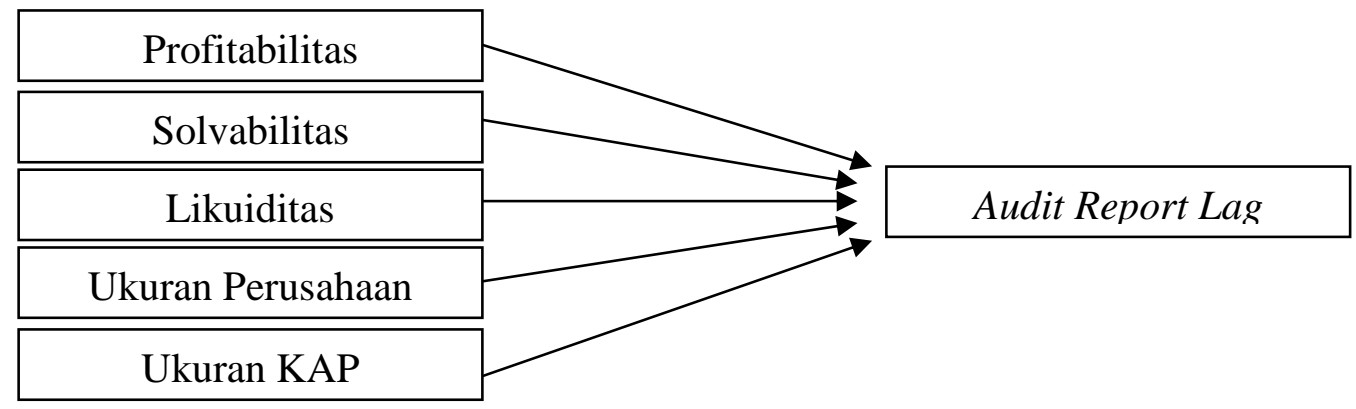

\section{Hipotesis}

\section{Pengaruh Profitabilitas terhadap Audit Report Lag}

Menurut (Sartika, 2017) profitabilitas adalah ukuran kemampuan dalam menghasilkan keuntungan selama periode tertentu. Profitabilitas diproksikan return on asset (ROA). ROA merupakan rasio atas jumlah aset yang digunakan berdasarkan perbandingan laba bersih setelah pajak dengan total aset. Nilai ROA yang tinggi menunjukkan efisien dalam menggunakan asetnya dalam memperoleh laba. profit merupakan informasi baik. Semakin tinggi profitabilitas maka semakin besar memengaruhi audit report lag karena akan segera menyampaikan informasi baik. Entitas dengan profitabilitas lebih tinggi membutuhkan waktu pengauditan laporan keuangan lebih cepat karena untuk secepatnya menyampaikan kabar baik kepada publik. Entitas yang menghasilkan tingkat profitabilitas yang lebih tinggi maka audit report lag akan lebih pendek dibandingkan perusahaaan dengan tingkat profitabilitas yang lebih rendah. Penelitian (Artaningrum et al., 2017), (Ayuningtyas \& Riduwan, 2020), (Deasy \& Iskak, 2021), (Fadrul et al., 2021), (Lesmana, 2021), (Mahendra, 2021), (Menajang et al., 2019), (Rahayu et al., 2021), (Sartika, 2017), (Sastrawan \& Latrini, 2016), (Siregar \& Sujiman, 2021), (Tampubolon \& Siagian, 2020), dan (Widiastuti \& Kartika, 2018) menunjukkan bahwa profitabilitas berpengaruh negatif terhadap audit report lag. Rumusan hipotesis pertama adalah:

H1: Profitabilitas berpengaruh negatif terhadap Audit Report Lag 


\section{Pengaruh Solvabilitas terhadap Audit Report Lag}

Solvabilitas diproksikan dengan debt to equity ratio (DER). DER merupakan rasio untuk menilai utang dengan ekuitas. Nilai DER yang tinggi menunjukkan banyaknya utang yang ditanggung entitas di dalam sumber pendanaan. Solvabilitas tinggi mencerminkan tingginya risiko keuangan karena entitas mengalami kesulitan keuangan. Hal tersebut adalah berita buruk bagi citra entitas di mata publik sehingga menyebabkan manajemen akan menunda pelaporan keuangannya. Penelitian (Artaningrum et al., 2017), (Lesmana, 2021), (Sastrawan \& Latrini, 2016), (Setyawan, 2020), (Siregar \& Sujiman, 2021), (Widiastuti \& Kartika, 2018), dan (Yunita et al., 2020) menunjukkan solvabilitas berpengaruh positif terhadap audit report lag. Rumusan hipotesis ketiga adalah:

H2: Solvabilitas berpengaruh positif terhadap Audit Report Lag

\section{Pengaruh Likuiditas terhadap Audit Report Lag}

Likuiditas diproksikan current ratio (CR) untuk menilai total aset lancar dengan utang jangka pendek. CR untuk mengukur kemampuan membayar kewajiban jangka pendek atau utang yang segera jatuh tempo pada saat ditagih secara keseluruhan dengan aset lancar. Semakin tinggi tingkat likuiditas maka kinerja baik karena kemampuan tinggi dalam melunasi kewajibannya sehingga manajemen akan lebih cepat menyampaikan laporan keuangannya. Hal ini merupakan berita baik sehingga cenderung tepat waktu menyampaikan laporan keuangannya. Penelitian (Artaningrum et al., 2017), (Ayuningtyas \& Riduwan, 2020), dan (Suginam, 2016) menunjukkan likuiditas berpengaruh positif terhadap audit report lag. Likuiditas mempunyai pengaruh secara signifikan terhadap ketepatan waktu penyampaian laporan keuangan sehingga dapat dirumuskan hipotesis ketiga:

H3: Likuiditas berpengaruh negatif terhadap Audit Report Lag

\section{Pengaruh Ukuran Entitas terhadap Audit Report Lag}

Ukuran entitas diproksikan dengan berdasar pada total aset. Ukuran entitas memiliki pengaruh terhadap audit report lag. Entitas besar cenderung lebih tepat waktu dalam penyajian laporan keuangan auditannya karena memiliki beberapa kepentingan yang menuntut untuk segera menerbitkan laporan auditan. Penelitian (Artaningrum et al., 2017), (Ayuningtyas \& Riduwan, 2020), (Siregar \& Sujiman, 2021), (Widiastuti \& Kartika, 2018), dan (Yunita et al., 2020) menunjukkan faktor ukuran entitas berhubungan negatif dengan audit report lag. Berdasar hal tersebut maka dapat dirumuskan hipotesis ketiga:

H4: Ukuran entitas berpengaruh negatif terhadap Audit Report Lag

\section{Pengaruh Ukuran KAP terhadap Audit Report Lag}

Ukuran KAP diproksikan variabel dummy berdasar pada KAP big four dan KAP nonbig four. KAP dengan reputasi baik cenderung memiliki banyak sumber daya berkompeten untuk melaksanakan prosedur audit secara lebih efisien dan efektif sehingga laporan audit dapat terselesaikan tepat waktu. Kantor akuntan publik dengan afiliasi Big Four memiliki strategi penemuan bukti-bukti yang diperlukan dalam proses audit. Big Four didukung oleh ahli-ahli yang kompeten dan memiliki kecanggihan teknologi dibandingkan non-Big Four sehingga dapat menyelesaikan laporan keuangan secara tepat waktu. Selain itu menurut (Mahendra, 2021) KAP Big four harus menjaga kredibilitas mereka dimata para investor sehingga sebisa mungkin auditor dari KAP Big four akan bekerja secara profesional sehingga syarat akan waktu akan menjadi pertimbangan yang sangat besar. Dengan begitu KAP Big four akan lebih dapat mengurangi lag dibanding KAP non-Big Four. Berdasar hal tersebut maka hipotesis kelima: 
Owner: Riset \& Jurnal Akuntansi

e-ISSN : 2548-9224 |p-ISSN : 2548-7507

Volume 6 Nomor 1, Januari 2022

DOI : https://doi.org/10.33395/owner.v6i1.704

H5: Ukuran KAP berpengaruh negatif terhadap Audit Report Lag

\section{METODE}

\section{Populasi dan Sampel}

Populasi adalah keseluruhan objek penelitian dan memenuhi karakteristik tertentu (Bahri, 2018). Populasi penelitian entitas sektor perdagangan, jasa dan investasi yang terdaftar di Bursa Efek Indonesia periode 2017-2019. Pengambilan sampel berdasarkan kriteria:

1. Entitas sektor perdagangan, jasa dan investasi yang terdaftar di Bursa Efek Indonesia dan konsisten selama periode 2017-2019.

2. Melaporkan laba selama periode penelitian.

3. Dinyatakan dengan mata uang rupiah.

Table 1 Prosedur Pemilihan Sampel

\begin{tabular}{|l|c|}
\hline \multicolumn{1}{|c|}{ Kriteria } & Jumlah \\
\hline $\begin{array}{l}\text { Entitas sektor perdagangan, jasa dan investasi yang } \\
\text { terdaftar di Bursa Efek Indonesia periode 2017-2019 }\end{array}$ & 164 \\
\hline Tidak konsisten selama periode 2017-2019 & $(70)$ \\
\hline $\begin{array}{l}\text { Konsisten terdaftar di Bursa Efek Indonesia selama } \\
\text { periode 2017-2019 }\end{array}$ & 94 \\
\hline Mengalami rugi selama periode penelitian & $(40)$ \\
\hline Mengalami laba selama periode penelitian & 54 \\
\hline $\begin{array}{l}\text { Laporan keuangan tidak dinyatakan dengan mata uang } \\
\text { rupiah }\end{array}$ & $(3)$ \\
\hline $\begin{array}{l}\text { Laporan keuangan dinyatakan dengan mata uang rupiah } \\
\text { dan sekaligus sebagai sampel penelitian }\end{array}$ & 51 \\
\hline
\end{tabular}

Setelah kriteria ditetapkan dan dilakukan proses seleksia sampel maka diperoleh jumlah sampel yaitu sebanyak 51 entitas sektor perdagangan, jasa dan investasi. Periode penelitian 3 tahun maka jumlah data $\mathrm{n}=153$.

\section{Definisi Operasional}

1. Profitabilitas diproksikan return on asset (ROA). ROA merupakan pengukuran efisiensi aset dalam memperoleh laba dengan perbandingan laba bersih setelah pajak dengan jumlah aset. Mengacu (Muslichah \& Bahri, 2021) rumus ROA:

$$
\mathrm{ROA}=\frac{\text { Laba bersih }}{\text { Jumlah aset }}
$$

2. Solvabilitas diproksikan debt to equity ratio (DER). DER menunjukkan banyaknya utang yang ditanggung entitas di dalam susunan modal. Menurut (Muslichah \& Bahri, 2021) perhitungan DER adalah.

$$
\text { DER }=\frac{\text { Jumlah kewajiban }}{\text { Jumlah Ekuitas }}
$$

3. Likuiditas diproksikan current ratio (CR) untuk menilai total aset lancar dengan utang jangka pendeknya. Menghitung CR adalah.

$$
\mathrm{CR}=\frac{\text { Aset lancar }}{\text { Kewajiban jangka pendek }}
$$


4. Ukuran entitas diproksikan berdasar jumlah aset yang dimiliki. Ukuran entitas dihitung: Ukuran Perusahaan $=$ LN Total Aset

5. Ukuran KAP merupakan variabel dummy KAP big four dan KAP non-big four. Kategori dummy 1 untuk entitas yang menggunakan KAP yang berafiliasi dengan the big four dan dummy 0 untuk entitas yang tidak menggunakan KAP yang berafiliasi dengan the big four.

6. Audit report lag diukur dari tanggal tutup buku entitas sampai tanggal laporan auditor independen. Audit Report Lag = Tanggal Laporan Audit - Tanggal Laporan Keuangan

\section{Normalitas Data}

\section{HASIL}

Normalitas data merupakan uji distribusi data dengan memperhatikan tingkat penyebaran di bawah kurva normal atau tidak dengan pendekatan one-sample kolmogorov-smirnov dengan nilai test statistic 0,136 dan signifikansi 0,073 dengan kesimpulan residual data berdistribusi normal.

\section{Koefisien Determinasi}

\begin{tabular}{l|c|r|r|r|r}
\multicolumn{7}{c}{ Table 2 Koefisien Determintasi } \\
Model & $\mathrm{R}$ & $\begin{array}{c}\mathrm{R} \\
\text { Square }\end{array}$ & $\begin{array}{c}\text { Adjusted R } \\
\text { Square }\end{array}$ & $\begin{array}{c}\text { Std. Error of } \\
\text { the Estimate }\end{array}$ & $\begin{array}{c}\text { Durbin- } \\
\text { Watson }\end{array}$ \\
\hline 1 &, $230^{\mathrm{a}}$ &, 053 &, 021 & 24,47171 & 1,941 \\
\hline
\end{tabular}

Nilai multiple R pada tabel 2 sebesar 0,230 yang jauh dari 1, artinya hubungan ROA, DER, CR, SIZE dan KAP terhadap ARL lemah. Nilai R Square sebesar 0,053 menjelaskan nilai ARL sebesar 0,053 atau 5,3\%. Maka ARL hanya dijelaskan sebesar 5,3\% oleh variabel ROA, DER, CR, SIZE dan KAP, sisanya dijelaskan oleh variabel lain yang tidak terdapat di model. Nilai Adjusted $R$ Square sebesar 0,021 atau 2,1\% merupakan nilai kemampuan variabel ROA, DER, CR, SIZE dan KAP untuk menjelaskan variabel ARL.

\section{Uji Autokorelasi}

Nilai uji autokorelasi dengan Durbin-Watson (DW) dengan signifikansi 5\% pada tabel 2 menunjukkan angka 1,941. Jumlah sampel $\mathrm{n}=153$, dan jumlah variabel $\mathrm{k}=4$. Nilai $\mathrm{dl}=$ 1,6824 dan nilai du $=1,7896$. Nilai DW 1,941 <2,2104 dan nilai DW 1,941 > 1,7896. Nilai DW berada di daerah tidak ada autokorelasi sehingga tidak terdapat gejala autokorelasi.

\section{Multikolinieritas}

Nilai Variance Inflation Factor (VIF) variabel ROA $=1,156, \mathrm{DER}=1,490, \mathrm{CR}=$ 1,384 , SIZE $=1,278$ dan variabel KAP sebesar 1,202. Nilai VIF kelima variabel independen $<10$ atau tidak berada di atas 10 sehingga tidak terjadi multikolinieritas antara setiap variabel independen dalam model regresi.

\section{Regresi Linier Berganda}

Table 3 Regresi Linier Berganda

\begin{tabular}{|c|c|c|c|c|c|c|}
\hline \multirow{2}{*}{\multicolumn{2}{|c|}{ Model }} & \multicolumn{2}{|c|}{$\begin{array}{c}\text { Unstandardized } \\
\text { Coefficients }\end{array}$} & \multirow{2}{*}{$\begin{array}{c}\text { Standardized } \\
\text { Coefficients } \\
\text { Beta } \\
\end{array}$} & \multirow[b]{2}{*}{$\mathrm{t}$} & \multirow[b]{2}{*}{ Sig. } \\
\hline & & $\mathrm{B}$ & Std. Error & & & \\
\hline \multirow[t]{3}{*}{1} & (Constant) & 137,934 & 43,476 & & 3,173 & ,002 \\
\hline & ROA & $-42,034$ & 19,071 &,- 190 & $-2,204$ &, 029 \\
\hline & DER & $-12,519$ & 6,418 &,- 191 & $-1,951$ &, 053 \\
\hline
\end{tabular}


Owner: Riset \& Jurnal Akuntansi

e-ISSN : 2548-9224 | p-ISSN : 2548-7507

Volume 6 Nomor 1, Januari 2022

DOI : https://doi.org/10.33395/owner.v6i1.704

\begin{tabular}{l|l|r|r|r|r|r}
\hline \multirow{2}{*}{ CR } & $-3,739$ & 3,156 &,- 112 & $-1,185$ &, 238 \\
\cline { 2 - 7 } & SIZE & $-1,048$ & 1,499 &,- 063 &,- 699 &, 486 \\
\cline { 2 - 7 } & Ukuran KAP & 4,179 & 4,379 &, 084 &, 954 &, 341 \\
\hline
\end{tabular}

Konstanta 137,934 menjukan nilai ARL jika tidak terdapat variabel ROA, DER, CR, SIZE dan KAP. Nilai konstanta positif diasumsikan nilai ARL akan naik 137,934 saat variabel bebas konstan. Nilai ROA -42,034 bernilai negatif menunjukkan hubungan terbalik terhadap ARL. Jika ROA naik satu satuan maka ARL akan turun sebesar 42,034 dan sebaliknya. Nilai DER $-12,519$ bernilai negatif menunjukkan hubungan terbalik terhadap ARL. Jika DER naik satu satuan maka ARL akan turun sebesar 12,519 dan sebaliknya. Nilai CR $-3,739$ bernilai negatif menunjukkan hubungan terbalik terhadap ARL. Jika CR naik satu satuan maka ARL akan turun sebesar 3,739 dan sebaliknya. Nilai SIZE -1,048 bernilai negatif menunjukkan hubungan terbalik terhadap ARL. Jika SIZE naik satu satuan maka ARL akan turun sebesar 1,048 dan sebaliknya. Nilai KAP 4,179 bernilai positif menunjukkan hubungan searah terhadap ARL. Jika KAP naik satu satuan maka ARL akan naik sebesar 4,179 dan sebaliknya.

\section{Uji Hipotesis}

Variabel ROA signifikansi 0,029 < 0,050 maka ROA berpengaruh negatif signifikan terhadap ARL sehingga hipotesis pertama diterima. Variabel DER signifikansi 0,053>0,050 maka DER tidak berpengaruh terhadap ARL sehingga hipotesis kedua ditolak. Variabel CR signifikansi 0,238 > 0,050 maka CR tidak berpengaruh terhadap ARL sehingga hipotesis ketiga ditolak. Variabel SIZE signifikansi 0,486 > 0,050 maka SIZE tidak berpengaruh terhadap ARL sehingga hipotesis keempat ditolak. Variabel ukuran KAP signifikansi 0,341 $>$ 0,050 maka ukuran KAP tidak berpengaruh signifikan terhadap ARL sehingga hipotesis kelima ditolak.

\section{PEMBAHASAN \\ Pengaruh Profitabilitas terhadap Audit Report Lag}

Rasio profitabilitas berpengaruh negatif signifikan terhadap audit report lag. Entitas yang meningkat rasio profitabilitasnya akan berkurang jumlah hari atau audit report lag dalam penyampaian laporan keuangan auditannya. Sebaliknya, entitas yang menurun rasio profitabilitasnya akan bertambah jumlah hari atau audit report lag dalam penyampaian laporan keuangan auditannya. Pengaruh signifikan menjelaskan jika pengaruh rasio profitabilitas entitas sangat penting terhadap audit report lag. Hasil penelitian sesuai dengan penelitian (Artaningrum et al., 2017), (Ayuningtyas \& Riduwan, 2020), (Deasy \& Iskak, 2021), (Fadrul et al., 2021), (Lesmana, 2021), (Mahendra, 2021), (Menajang et al., 2019), (Rahayu et al., 2021), (Sartika, 2017), (Sastrawan \& Latrini, 2016), (Siregar \& Sujiman, 2021), (Tampubolon \& Siagian, 2020), dan (Widiastuti \& Kartika, 2018) bahwa profitabilitas berpengaruh negatif terhadap audit report lag. Namun hasil penelitian tidak mendukung temuan (Suginam, 2016), (Sunarsih et al., 2021), (Tannuka, 2018), dan (Yunita et al., 2020).

\section{Pengaruh Solvabilitas terhadap Audit Report Lag}

Rasio solvabilitas tidak berpengaruh terhadap audit report lag. Entitas yang meningkat rasio solvabilitasnya akan berkurang jumlah hari atau audit report lag dalam penyampaian laporan keuangan auditannya. Sebaliknya Entitas yang menurun rasio solvabilitasnya akan 
bertambah jumlah hari atau audit report lag dalam penyampaian laporan keuangan auditannya. Namun pengaruh yang tidak signifikan menjelaskan jika nilai rasio solvabilitas entitas berpengaruh lemah atau tidak memiliki pengaruh terhadap audit report lag. Hasil penelitian sesuai dengan temuan (Ayuningtyas \& Riduwan, 2020), (Deasy \& Iskak, 2021), (Fadrul et al., 2021), (Mahendra, 2021), (Menajang et al., 2019), (Rahayu et al., 2021), (Sartika, 2017), (Suginam, 2016), dan (Tannuka, 2018) bahwa solvabilitas tidak berpengaruh terhadap audit report lag. Namun hasil penelitian tidak mendukung temuan (Artaningrum et al., 2017), (Sastrawan \& Latrini, 2016), (Setyawan, 2020), (Siregar \& Sujiman, 2021), (Sunarsih et al., 2021), (Tampubolon \& Siagian, 2020), (Widiastuti \& Kartika, 2018), dan (Yunita et al., 2020).

\section{Pengaruh Likuiditas terhadap Audit Report Lag}

Rasio likuiditas memiliki hubungan negatif dengan pengaruh tidak signifikan terhadap audit report lag. Entitas yang meningkat rasio likuiditasnya akan berkurang jumlah hari atau audit report lag dalam penyampaian laporan keuangan auditannya. Sebaliknya Entitas yang menurun rasio likuiditasnya akan bertambah jumlah hari atau audit report lag dalam penyampaian laporan keuangan auditannya. Hasil penelitian menunjukkan likuiditas tidak berpengaruh. Nilai rasio likuiditas berpengaruh lemah atau tidak memiliki pengaruh terhadap audit report lag. Hasil penelitian sesuai dengan penelitian (Fadrul et al., 2021), (Setyawan, 2020), dan (Tannuka, 2018) bahwa likuiditas tidak berpengaruh terhadap audit report lag. Hasil penelitian tidak mendukung temuan (Artaningrum et al., 2017), (Ayuningtyas \& Riduwan, 2020), (Sartika, 2017), (Suginam, 2016), dan (Tampubolon \& Siagian, 2020).

\section{Pengaruh Ukuran Entitas terhadap Audit Report Lag}

Ukuran entitas memiliki hubungan negatif pengaruh tidak signifikan terhadap audit report lag. Meningkatnya ukuran entitas akan berkurang jumlah hari atau audit report lag dalam penyampaian laporan keuangan auditannya. Sebaliknya ukuran yang semakin kecil akan bertambah jumlah hari atau audit report lag dalam penyampaian laporan keuangan auditannya. Hasil penelitian menunjukkan bahwa ukuran entitas tidak berpengaruh. Besar kecilnya entitas tidak berdampak pada waktu pennyampaian laporan keuangan. Hasil ini sesuai dengan penelitian (Deasy \& Iskak, 2021), (Fadrul et al., 2021), (Mahendra, 2021), (Menajang et al., 2019), (Rahayu et al., 2021), (Sastrawan \& Latrini, 2016), (Suginam, 2016), dan (Tannuka, 2018). Namun hasil penelitian tidak mendukung temuan (Artaningrum et al., 2017), (Ayuningtyas \& Riduwan, 2020), (Setyawan, 2020), (Siregar \& Sujiman, 2021), (Sunarsih et al., 2021), (Widiastuti \& Kartika, 2018), dan (Yunita et al., 2020).

\section{Pengaruh Ukuran KAP terhadap Audit Report Lag}

Ukuran KAP memiliki hubungan positif pengaruh tidak signifikan terhadap audit report lag. Entitas yang menggunakan jasa audit KAP big four memiliki kecenderungan akan bertambah jumlah hari atau audit report lag dalam penyampaian laporan keuangan auditannya. Sebaliknya penggunaan jasa audit KAP non-big four cenderung lebih cepat dalam penyampaian laporan keuangan auditannya. Namun pengaruh ukuran KAP tidak signifikan menjelaskan jika ukuran KAP berpengaruh lemah atau tidak memiliki pengaruh terhadap audit report lag. Hasil penelitian sesuai dengan temuan (Fadrul et al., 2021) dan (Mahendra, 2021). Namun hasil penelitian tidak mendukung temuan (Ayuningtyas \& Riduwan, 2020), (Rahayu et al., 2021), (Tannuka, 2018), dan (Widiastuti \& Kartika, 2018). 


\section{KESIMPULAN}

Hasil penelitian bahwa profitabilitas berpengaruh negatif signifikan terhadap audit report lag, menjelaskan laba memengaruhi waktu penyampaian laporan keuangan auditan. Variabel solvabilitas, likuiditas, ukuran entitas, dan ukuran KAP tidak berpengaruh terhadap audit report lag. Tidak berpengaruhnya keempat variabel tersebut maka perbandingan sumber pendanaan, kemampuan membayar utang jangka pendek, besar kecilnya aset, dan besar kecilnya KAP yang digunakan tidak memengaruhi audit report lag. Kecilnya pengaruh variabel independen terhadap audit report lag dengan dibuktikan tingkat adjusted $r$ square sehingga disarankan peneliti selanjutnya untuk mengembangkan populasi dan variabel-variabel independen lainnya. Peneliti selanjutnya dapat mengembangkan variabel independen seperti opini auditor, umur perusahaan, laba rugi, good corporate governance dan lainnya.

\section{REFERENSI}

Artaningrum, R. G., Budiartha, I. K., \& Wirakusuma, M. G. (2017). Pengaruh Profitabilitas, Solvabilitas, Likuiditas, Ukuran Perusahaan Dan Pergantian Manajemen Pada Audit Report Lag Perusahaan Perbankan. 6(3), 1079-1108.

Asnawi, S. K., \& Wijaya, C. (2005). Riset Keuangan: Pengujian-Pengujian Empiris. Gramedia Pustaka Utama.

Ayuningtyas, M. I., \& Riduwan, A. (2020). Pengaruh Profitabilitas, Likuiditas, Solvabilitas, Ukuran Perusahaan, Dan Reputasi Akuntan Publik Terhadap Audit Report Lag. Jurnal Ilmu Dan Riset Akuntansi, 9(3), 1-21.

Bahri, S. (2017). Faktor-Faktor Yang Mempengaruhi Kebijakan Dividen (Studi Pada Perusahaan Manufaktur yang Terdaftar di BEI). Jurnal Riset Akuntansi \& Komputerisasi Akuntansi, 8(1), 63-84.

Bahri, S. (2018). Metodologi Penelitian Bisnis Lengkap Dengan Pengolahan Data SPSS (1st ed.). Penerbit Andi.

Bursa Efek Indonesia. (2004). Keputusan Direksi PT Bursa Efek Jakarta Nomor: Kep306/BEJ/07-2004 Tentang Peraturan Nomor I-E Tentang Kewajiban Penyampaian Informasi. Jakarta.

Bursa Efek Indonesia. (2021). Surat Keputusan Direksi PT Bursa Efek Indonesia Nomor: Kep-00015/BEI/01-2021 Tentang Kewajiban Penyampaian Informasi.

Deasy, S., \& Iskak, J. (2021). Pengaruh Likuiditas, Solvabilitas Dan Ukuran Perusahaan Terhadap Audit Report Lag. Jurnal Multiparadigma Akuntansi, 3(4), 1748-1755. https://doi.org/10.31629/jiafi.v4i1.2697

Fadrul, Lianto, K., \& Febriansyah, E. (2021). Analisis Pengaruh Profitabilitas, Solvabilitas, Likuiditas, Ukuran Perusahaan, Dan Reputasi Auditor Terhadap Audit Report Lag Pada Perusahaan Sektor Perdagangan Besar Yang Terdaftar Di Bursa Efek Indonesia Periode 2015-2019. Jurnal Akuntansi, Kewirausahaan, Dan Bisnis, 6(1), 78-90. http://www.ejournal.pelitaindonesia.ac.id/ojs32/index.php/KURS/index

Kementerian Keuangan Republik Indonesia. (2008). Peraturan Menteri Keuangan Nomor 17/PMK.01/2008 Tentang Jasa Akuntan Publik. Jakarta.

Lesmana, K. K. (2021). Pengaruh Profitabilitas, Solvabilitas Dan Ukuran Perusahaan Terhadap Audit Report Lag. JRAK Jurnal Riset Akuntansi Dan Bisnis, 7(1), 84-92.

Mahendra, I. G. P. W. (2021). Pengaruh Profitabilitas, Solvabilitas, Ukuran Perusahaan, Opini Auditor, dan Reputasi KAP Terhadap Audit Report Lag Pada Perusahaan Bidang Manufaktur Terdaftar di BEI Pada Tahun 2016-2020. Prosiding: Ekonomi Dan Bisnis, $1(1)$. 
Menajang, M. J. O., Elim, I., \& Runtu, T. (2019). Analisis Pengaruh Ukuran Perusahaan, Profitabilitas, Dan Solvabilitas Terhadap Audit Report Lag (Studi Kasus Perusahaan Property Dan Real Estate Yang Terdaftar Di Bursa Efek Indonesia). Jurnal EMBA: Jurnal Riset Ekonomi, Manajemen, Bisnis Dan Akuntansi, 7(3), 3478-3487. https://doi.org/10.35794/emba.v7i3.24563

Muslichah, \& Bahri, S. (2021). Akuntansi Manajemen (Teori dan Aplikasi) (1st ed.). Mitra Wacana Media Penerbit.

Nurdiana, A. (2019). Masih ada 107 emiten belum menyampaikan laporan keuangan semester I-2019. Kontan. Https://Investasi.Kontan.Co.Id/News/Masih-Ada-107Emiten-Belum-Menyampaikan-Laporan-Keuangan-Semester-i-2019.

Rahayu, P., Khikmah, S. N., \& Dewi, V. S. (2021). Pengaruh Ukuran Perusahaan, Profitabilitas, Solvabilitas, Ukuran KAP Dan Financial Distress Terhadap Audit Report Lag. Business and Economics Conference in Utilization of Modern Technology, 4.

Ross, S. A. (1977). The Determination Of Financial Structure: The Incentive Signalling Approach. The Bell Journal Of Economics, 8(1), 23-40.

Sartika, S. D. (2017). Pengaruh Profitabilitas, Likuiditas dan Solvabilitas Terhadap Audit Reporting Lag (Studi Empiris Pada Perusahaa Perbankan yang Terdaftar di Bursa Efek Indonesia Tahun 2011-2015). Jurnal Akuntansi, 5(1), 2-22.

Sastrawan, I. P., \& Latrini, M. Y. (2016). Pengaruh Profitabilitas, Solvabilitas, Dan Ukuran Perusahaan Terhadap Audit Report Lag Pada Perusahaan Manufaktur. E-Jurnal Akuntansi Universitas Udayana, 17(1), 311-337.

Setyawan, N. H. (2020). Pengaruh Likuiditas, Solvabilitas Dan Ukuran Perusahaan Terhadap Audit Report Lag. Jurnal Ilmiah Akuntansi Dan Finansial Indonesia, 4(1), 27-40. https://doi.org/10.31629/jiafi.v4i1.2697

Siregar, I. U., \& Sujiman, L. S. (2021). Pengaruh Profitabilitas, Solvabilitas Dan Ukuran Perusahaan Terhadap Audit Report Lag Pada Perusahaan Manufaktur Sub Sektor Makanan Dan Minuman Yang Terdaftar Di BEI 2018 - 2020. Jurnal Ekonomi Dan Bisnis, 14(3D), 4-19.

Suginam. (2016). Faktor-Faktor Yang Mempengaruhi Audit Report Lag Pada Perusahaan Sektor Perdagangan Jasa Dan Investasi Yang Terdaftar Di Bursa Efek Indonesia. Majalah Ilmiah Informasi Dan Teknologi Ilmiah, 11(1), 61-71.

Sunarsih, N. M., Munidewi, I. A. B., \& Masdiari, N. K. M. (2021). Pengaruh Ukuran Perusahaan, Profitabilitas, Solvabilitas, Kualitas Audit, Opini Audit, Komite Audit Terhadap Audit Report Lag. KRISNA: Kumpulan Riset Akuntansi, 13(1), 1-13. https://doi.org/10.22225/kr.13.1.2021.1-13

Tambunan, P. U. (2014). Pengaruh Opini Audit, Pergantian Auditor dan Ukuran Kantor Akuntan Publik Terhadap Audit Report Lag (Studi Empiris Pada Perusahaan Manufaktur yang Terdaftar di Bursa Efek Indonesia ). Jurnal Akuntansi, 2(2), 1-18.

Tampubolon, R. R., \& Siagian, V. (2020). Pengaruh Profitabilitas, Solvabilitas, Likuiditas Dan Audit Tenure Terhadap Audit Report Lag Dengan Komite Sebagai Pemoderasi. Jurnal Ekonomi Modernisasi, 16(2), 82-95. https://doi.org/10.21067/jem.v16i2.4954

Tannuka, S. (2018). Pengaruh Ukuran Perusahaan, Profitabilitas, Solvabilitas, Likuiditas, Dan Ukuran Kap Terhadap Audit Report Lag (Studi Empiris Pada Perusahaan Properti, Real Estate, Dan Konstruksi Bangunan Yang Terdaftar Di Bursa Efek Indonesia Periode 2011-2015). Jurnal Muara Ilmu Ekonomi Dan Bisnis, 2(2), 354-368. https://doi.org/10.24912/jmieb.v2i2.1312

Widiastuti, I. D., \& Kartika, A. (2018). Ukuran Perusahaan, Profitabilitas, Umur Perusahaan, Solvabilitas dan Ukuran Kap Terhadap Audit Report Lag. Dinamika Akuntansi, 
Owner: Riset \& Jurnal Akuntansi

e-ISSN : 2548-9224 | p-ISSN : 2548-7507

Volume 6 Nomor 1, Januari 2022

Keuangan Dan Perbankan, 20-34. https://www.unisbank.ac.id/ojs/index.php/fe9/article/view/7443

Yunita, N. M. yuliana, Adnantara, K. F., \& Kusumadewi, T. (2020). Pengaruh Profitabilitas, Solvabilitas, Dan Dukuran Perusahaan Terhadap Audit Report Lag Pada Perusahaan Manufaktur Yang Terdaftar Di Bursa Efek Indonesia Periode 2016-2018. Journal Research Accounting, 02(1), 83-92. 